\title{
PELATIHAN PENGELASAN SMAW BAGI KARANG TARUNA KELURAHAN TEMAS KECAMATAN BATU KOTA BATU
}

\author{
Arif Rochman Fachrudin *1, Fina Andika Frida Astuti ${ }^{2}$, Mira Esculenta Martawati ${ }^{3}$, Ahmad Hanif ${ }^{4}$ \\ 1,2,3,4 Ipoliteknik Negeri Malang \\ *e-mail: arifrochman.f@polinema.ac.id ${ }^{1}$ fina.andika@polinema.ac.id ${ }^{2}$ \\ mira.esculenta@polinema.ac.id ${ }^{3}$, ahmad.hanif@polinema.ac.id $^{4}$
}

\begin{abstract}
Higher education has an important role in Tri Darma, namely participating in the intellectual life of the nation and state in real life in society. One of the steps is to make humans no longer the object of development but the subject of development. As a development subject, it is necessary to have abilities and proficiency in mastery of science and technology. The use of welding technology has developed and is widely used and utilized in the wider community, both for the home industry scale and for repairing home appliances. One of the welding methods is SMAW welding, namely welding using an electric arc. The purpose of this activity is to increase general knowledge of youth youth groups in Temas Village, Batu District, Batu City, add special skills in the form of SMAW welding and provide encouragement and assistance so that the youth group of the village of tea able to procure welding equipment. The benefit of this activity is to provide knowledge and train skills in SMAW welding so that it can be used for personal development and social benefits.
\end{abstract}

Keywords: welding training, SMAW welding, welding.

\begin{abstract}
Abstrak
Perguruan Tinggi mempunyai peran penting dalam Tri Darma, yaitu ikut dalam mencerdaskan kehidupan bangsa dan negara sencara nyata di masyarakat. Salah satu langkahnya adalah menjadikan manusia bukan lagi menjadi obyek pembangunan tetapi menjadi subyek pembangunan. Sebagai subyek pembangunan tentunya diperlukan kemampuan dan kecakapan dalam penguasaan ilmu pengetahuan dan teknologi. Pemanfaatan teknologi pengelasan telah berkembang dan banyak digunakan dan dimanfaatkan ditengah masyarakat luas, baik untuk skala industri rumah tangga maupun untuk perbaikan perbaikan peralatan dirumah. Salah satu metode pengelasan adalah pengelasan SMAW, yaitu pengelasan dengan menggunakan busur listrik.Tujuan dari kegiatan ini adalah meningkatkan pengetahuan secara umum remaja karang taruna kelurahan Temas Kecamatan Batu kota Batu, menambah ketrampilan kusus berupa pengelasan SMAW dan memberikan dorongan dan bantuan sehingga karang taruna kampung teh mampu mengadakan peralatan las.Manfaat dari kegiatan ini adalah memberikan pengetahuan dan melatih ketrampilan dalam pengelasan SMAW sehingga bisa digunakan untuk pengembangan pribadi maupun manfaat secara sosial.
\end{abstract}

Kata kunci: pelatihan pengelasan, las SMAW, pengelasan.

\section{PENDAHULUAN}

Di era globalisasi ini, menuntut setiap orang mempunyai keahlian karena dengan mempunyai keahlian, seseorang akan mampu menahan tekanan yang begitu besar dari kebutuhan lapangan pekerjaan yang tidak seimbang dengan perkembangan penduduk, sehingga setiap orang berlomba lomba untuk meningkatkan pengetahuan dan ketrampilan.

Melihat fenomena tersebut pendidik di perguruan tinggi tentunya memiliki peranan penting di dalam meningkatkan pengetahuan, ketrampilan minat wirausaha mahasiswa. Paling tidak perguruan tinggi wajib mempersiapkan SDM dosen yang sanggup tidak cuma mentransfer teori-teori yang terpaut dengan bidang keilmuannya. namun sanggup membagikan paradigma baru untuk direalisasikan dalam kehidupan nyata. 
Salah satu ketrampilan yang sangat dibutuhkan dalam dunia industri adalah pengelasan. Ketrampilan dalam pengelasan juga dibutuhkan untuk membentu menyelesaikan pekerjaan rumah, yaitu merawat berbagai alat alat permesinan serta dapat digunakan sebagai modal berwiraswasta.

Pengelasan merupakan metode penyambungan logam elemen mesin dalam suatu konstruksi mesin (Bachtiar,2012). Penyambungan las ini sangat banyak diaplikasikan di dalam dunia industri karena mempunyai banyak kelebihan. Kelebihan sambungan las antara lain,penyambungan las menghasilkan hasil permanen.Sambungan las memiliki kekuatan lebih kokoh dibanding dengan kekuatan bahan dini apabila pada proses pengelasan memakai bahan tambah ataupun pengisi serta metode pengelasan dengan pas serta benar (Djatmika,RD.,2008). Sambungan las juga relatif hemat jika dilihat secara ekonomis. Pengelasan bisa digunakan ataupun dicoba di lapangan, tidak cuma digunakan dalam area pabrik saja.

Las SMAW merupan pengelasan dengan memakai tenaga listrik buat menyalakan elektrode (Epriyanto,2015). Pengelasan ini efektif dan praktis karena hanya membutuhkan alat sederhana dan elektrode dalam penggunaannya, sehingga jenis las ini sangat baik diaplikasikan dalam industri rumah tangga, misalnya pembuatan pagar, atau di lingkungan industri. Secara umum pengelasan digunakan sebagai penyambungan logam dan sebagai alat perawatan dari konstruksi mesin (BS EN ISO 2012).

Dalam proses pengelasan harus diperhatikan hal hal yang membahayakan bagi Kesehatan dan Keselamatan. Pemakaian APD berupa kacamata las, pakaian yang sesuai dan sepatu safety merupakan langkah aman dalam pengelasan (Anzy, 2012)

\section{METODE}

\section{Kerangka Kegiatan}

Untuk mencapai tujuan dan target dari pelatihan yang dilakukan maka perlu dilakukan beberapa tahap, seperti sosialisasi pelatihan, materi K3, Materi Pengelasan, proses pelaksanaan pelatihan, praktik lapangan, dan evaluasi. Gambar 1. Merupakan alur dari pelaksanaan pelatihan

Bersumber pada alur proses pendekatan pemecahan permasalahan tersebut disusunlah rencana serta penjawalan aktivitas dari pelatihan yang hendak dilaksanakan. Kegiatan di ikut oleh anggota Karang Taruna desa Temas RT 5/ RW 7 Batu. Pelaksanaan kegiatan pelatihan dilakukan selama 2 hari dari mulai tanggal 5-6 Juli 2020.

Alat yang digunakan adalah 1 Unit las listrik SMAW beserta elektrode, Bahan yang digunakan praktek adalah lembaran plat tebal 1,2 yang dipotong potong dan besi hollow. 


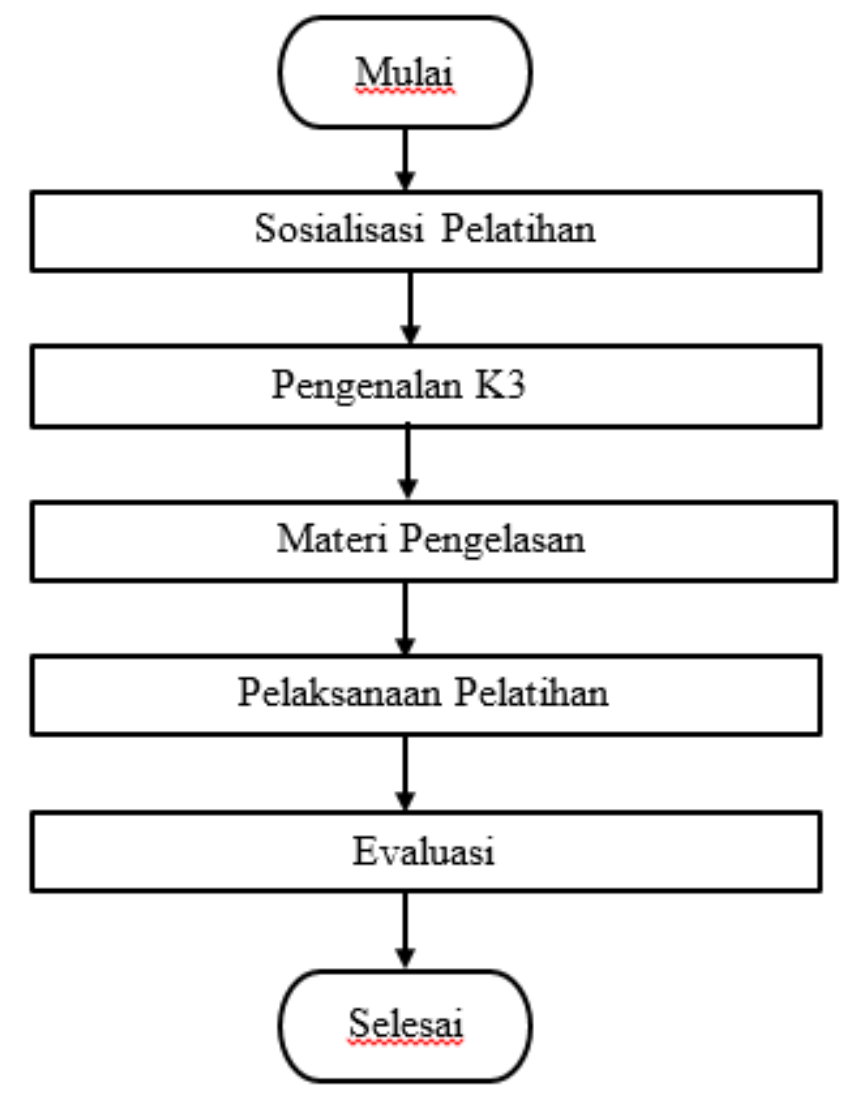

\section{Metode Pelaksanaan}

Proses pelatihan dilakukan selama 2 hari berturut-turut. Pelatihan diberikan dalam bentuk workshop dilengkapi dengan pemberian materi ajar. Praktik lapangan dengan memberikan contoh secara langsung di area praktik. Pada pelatihan diawali dengan penyampaian materi tentang K3 (Kesehatan dan Keselamatan Kerja) dan materi pengelasan SMAW. Selanjutnya diakukan pelatihan pengelasan SMAW dengan melakukan praktek secara langsung. peserta diminta untuk melakukan idenfitikasi dan juga pengaplikasian dari materi dan praktik yang telah diajar pada lingkungan di sekitar tempat praktik. Selama pelaksanaan pelatihan, dilakukan evaluasi dengan menilai secara langsung penguasaan materi dan ketrampilan praktis para peserta pelatihan. Selain itu dilakukan dialog dengan peserta pelatihan mengenai kesulitan yang dihadapi setelah pelaksanaan pelatihan. Beberapa dialog dari peserta diketahui bahwa pelatihan terkesan terlalu singkat pada pengelasan plat Hollow. Dengan pengetahuan praktek ini menambah percaya diri remaja karang taruna dalam bidang pengelasan SMAW. Secara umum para peserta memahami teori pengelasan dan membutuhkan latihan yang berkelanjutan untuk menghasilkan hasil yang lebih baik. 


\section{HASIL DAN PEMBAHASAN}

\section{Realisasi Pelaksanaan Kegiatan}

Kegiatan dilaksanakan sesuai dengan jadwal selama 2 Hari berturut-turut. Tempat pelaksanaan kegiatan Pelatihan Pengelasan SMAW bertempat JI Patimura Batu. Dokumentasi pelaksanaan pelatihan ditunjukkan pada gambar 2,3 dan gambar 4.

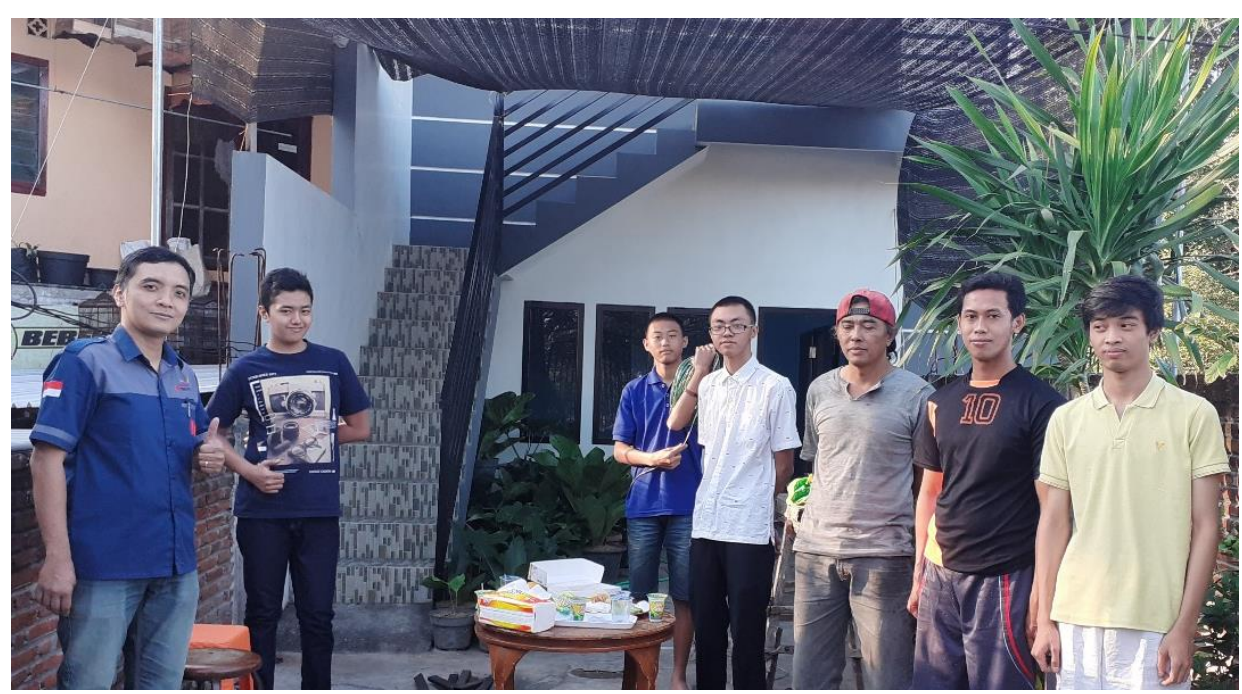

Gambar 2. Pelaksanaan PkM.

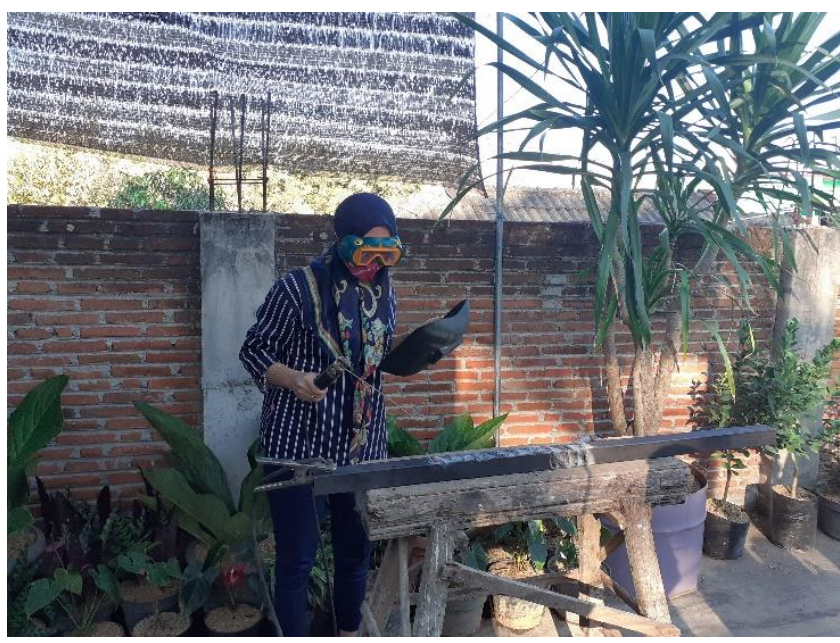

Gambar 3 Dokumentasi Pelatihan Pengelasan 


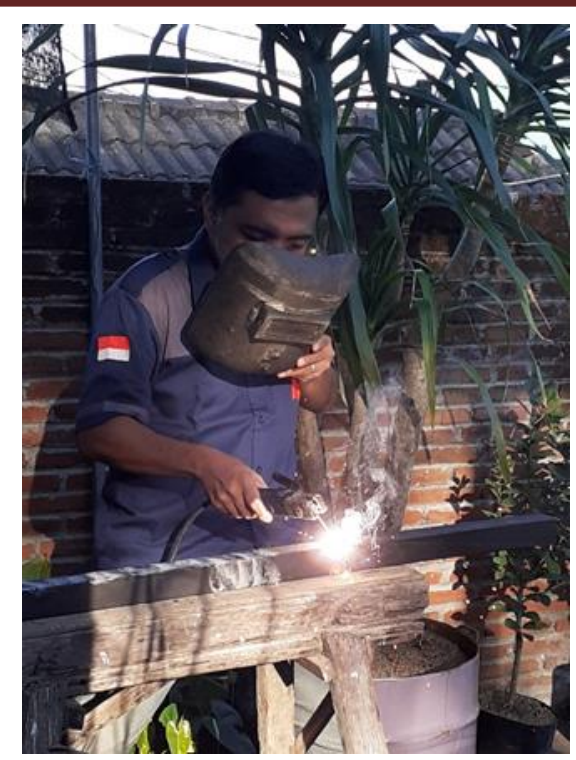

Gambar 4. Dokumentasi Pelatihan dan Pengelasan

\section{Sasaran Kegiatan}

Sasaran kegiatan Pengabdian kepada masyarakat ini adalah remaja Karang Taruna desa Temas Kota Batu. Background remaja Karang taruna berbagai macam, ada yang kerja serabutan, ada yang masih sekolah dan ada yang masih proses mencari kerja.

Serangkaian kegiatan sosialisasi ini memberikan temuan-temuan bagi pelaksana kegiatan. Temuan tersebut diantaranya:

a. Pada hari pertama, merupakan sosialisasi dan pengenalan awal dari materi. Sebagian besar peserta belum mengetahui apa itu Keselamatan dan Kesehatan Kerja (safety), bagaimana pentingnya safety dan apa itu sikap safety.

b. Hari Kedua, dilakukan pelatihan praktek pengelasan. Kegiatan interaksi yang terjadi sangatlah aktif, para peserta mulai memahami secara langsung bagaimana cara melakukan pengelasan SMAW.

Berdasarkan temuan yang telah dipaparkan diatas, dapat dilihat bahwa peserta mengikuti kegiatan dengan antusias. Selama 2 hari tersebut peserta telah mampu menunjukan beberapa sikap safety, meskipun pada awalnya mereka tidak tahu sama sekali. Selain itu anggapan bahwa bahaya seperti jatuh, terpercik minyak saat menggoreng, luka, dan lain sebagainya adalah hal yang biasa, sudah mulai bergeser dan disadari bahwa hal tersebut berdapak merugikan apalagi dalam jangka waktu yang panjang

\section{UCAPAN TERIMA KASIH (Bila Perlu)}

Penulis mengucapkan terima kasih kepada Direktur Politeknik Negeri Malang yang telah memberi dukungan terhadap pengabdian ini. 


\section{DAFTAR PUSTAKA}

ANSI Z49.1:2012, Safety in Welding, Cutting, and Allied Processes, Approved by the American National Standards Institute, March 9, 2012.

Bachtiar, ST., MT, Modul Ajar Praktek Las, Politeknik Perkapalan Negeri Surabaya, 2012.

BS EN ISO 5817 : 2017, Welding- Fusion- Welded joint in steel, nickel, titanium, and then alloys (beam welding excluded) quality levels for imperfections, www.bzfxw.com.

Epriyanto, Heat Input In Welding, PT. Bakrie Construction.

Hadi Kurniawanto, Hafidz Hanafiah, \& Ardi Hidayat. (2020). PENGEMBANGAN UMKM BONTOT SALMINAH SEBAGAI KULINER KHAS KOTA SERANG MENUJU ERA INDUSTRI 5.0. Jurnal Abdimas Bina Bangsa, 1(1), 1-14. doi:10.46306/jabb.v1i1.8

Pamungkas, M. D., \& Fadhilah Rahmawati. (2020). WORKSHOP PENGGUNAAN SOFTWARE GEOGEBRA SEBAGAI MEDIA PEMBELAJARAN MATEMATIKA BAGI GURU SD/MI. Jurnal Abdimas Bina Bangsa, 1(2), 176-185. doi:10.46306/jabb.v1i2.18

Riswan Dwi Djamiko, MPD, Modul Teori Pengelasan logam, Jurusan Pendidikan Teknik Mesin Fakultas Teknik Universitas Negeri Yogyakarta, 2008 